IN F ORMA T I K A

Jurnal Informatika, Manajemen dan Komputer, Vol.11 No.2, Desember 2019

eISSN :2580-3042

pISSN : 1979-0694

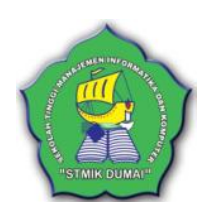

\title{
ALAT PENIRIS MINYAK OTOMATIS MANGGUNAKAN MIKROKOTROLER
}

\author{
Sukri Adrianto ${ }^{1}$, Muthia Kanza ${ }^{2}$ \\ ${ }^{1,2}$ Sekolah Tinggi Manajemen Informatika Dan Komputer (STMIK DUMAI) \\ JL. Utama Karya Bukit Batrem, Kota Dumai - Riau 28815 \\ e-mail : sukriadrianto@gmail.com ${ }^{1}$, kanzamuthia96@gmail.com ${ }^{2}$
}

\begin{abstract}
ABSTRAK
Keripik merupakan salah satu makanan ringan yang sangat disukai oleh masyarakat Indonesia, baik anak-anak, dewasa bahkan orang tua.Selain sebagai camilan, keripik sering dijadikan sebagai oleh-oleh khususnya pada keripik cabe. Salah satu proses pembuatan keripik cabe adalah dibutuhkannya proses penirisan, penirisan yang masih menggunakan cara manual yaitu dengan cara membiarkan beberapa jam sampai minyak turun ke dasar wadah, ini membuat waktu dalam penirisan cukup lama sehingga memunculkan ide peneliti untuk menciptakan alat peniris minyak otomatis menggunakan mikrokontroler. Jenis Miktokontroler yang digunakan adalah mikrokontroler Atmega328 atau yang sering disebut sebagai Arduino Uno yang digunakan sebagai pengontrol dalam proses penirisan secara otomatis, sehingga proses penirisan bisa lebih cepat. Dalam proses penirisan yang menggunakan timer ini dengan bantuan keypad yang dapat untuk mengatur berapa kecepatan dan waktu yang diperlukan, sehingga motor berputar dan berhenti sesuai inputan kecepatan dan waktu yang telah ditentukan dengan kata lain motor dapat berhenti secara otomatis. Selain mempercepat proses penirisan, minyak hasil dari proses penirisan bisa dimanfaatkan kembali dan juga bisa sebagai peluang usaha bagi masyarakat yang memiliki home industry.
\end{abstract}

Kata Kunci :Alat peniris, Mikrokontroler, Arduino Uno, keypad, motor DC.

\section{ABSTRACT}

Chips is one of the snacks that is very popular with the people of Indonesia, both children, adults and even parents. Apart from being a snack, chips are often used as souvenirs, especially for chile chips. One of the processes of making chilli chips is the need for draining processes, draining which still uses the manual method by letting a few hours until the oil drops to the bottom of the container, this makes the draining time long enough so that the ideas of researchers to create an automatic oil drainer using a microcontroller. The type of microcontroller used is the Atmega328 microcontroller or often called Arduino Uno which is used as a controller in the automatic draining process, so that the draining process can be faster. In the draining process that uses this timer with the help of a keypad that can adjust how much speed and time is needed, so that the motor rotates and stops according to the input speed and time specified in other words the motor can stop automatically. In addition to accelerating the draining process, the oil produced from the draining process can be reused and can also be a business opportunity for people who have a home industry.

Keywords : Spinner, Arduino Uno, Microcontroler, keypad, DC motor

\section{PENDAHULUAN}

Keripik merupakan salah satu makanan ringan yang sangat disukai oleh masyarakat Indonesia, baik anak-anak, dewasa bahkan orang tua. Selain sebagai camilan, keripik sering dijadikan sebagai buah tangan atau oleh-oleh bagi masyarakat khususnya masyarakat kota
Dumai yang dikenal dengan keripik cabenya salah satunya pada usaha Keripik Cabe $\mathrm{Hj}$. Karmi. Keripik cabe yang sudah menjadi oleholeh khas kota Dumai ini sering dibawa ke luar kota sehingga beberapa masyarakat dari luar kota Dumai menggunakan jasa pengiriman untuk bisa 


\section{INFORM TIK}

Jurnal Informatika, Manajemen dan Komputer, Vol.11 No.2, Desember 2019

eISSN :2580-3042

pISSN : 1979-0694

lagi merasakan keripik cabe tanpa harus kembali ke kota Dumai.

Salah satu proses pembuatan keripik cabe adalah dibutuhkannya proses penirisan. Penirisan pada dasarnya merupakan usaha untuk mengurangi kandungan minyak yang ada pada objek yang ditiriskan, di mana belum terdapatnya alat khususnya di tempat usaha Keripik Cabe $\mathrm{Hj}$. Karmi untuk meniriskan minyak yang terkandung pada keripik cabe, sehingga proses penirisan masih menggunakan cara manual yaitu dengan cara membiarkan beberapa jam sampai minyak turun ke dasar wadah, dan tidak semua keripik bisa dikemas karena keripik yang berada di dasar wadah terlalu banyak mengandung minyak sehingga tidak bagus untuk dikemas.

Untuk mengatasi permasalahan tersebut maka perlu adanya suatu perangkat yang dapat meniriskan minyak terutama minyak yang terkandung pada keripik cabe dengan memanfaatkan teknologi Miktokontroler Arduino Uno sebagai pengendali utama, keypad, driver 1298n, LCD 16x2, serta motor DC yang dirangkai sedemikian rupa menjadi sebuah perangkat peniris minyak yang dapat mempercepat waktu penirisan.

\section{a. Sistem}

Sistem secara sederhana dapat didefinisikan sebagai sekelompok elemen yang saling berhubungan atau berinteraksi hingga membentuk satu persatuan. Konsep umum sistem adalah sekelompok elemen yang saling berhubungan, bekerja sama untuk mencapai tujuan bersama dengan menerima input serta menghasilkan output dalam proses transformasi yang teratur. Selain itu juga, sistem adalah elemen-elemen yang terintegrasi dengan maksud untuk mencapai tujuan oragnisasi atau perusahaan yang terdiri atas sejumlah sumber daya.Sumber daya tersebut bekerja menuju tercapainya suatu tujuan tertentu yang ditentukan oleh pemilik atau manajemen perusahaan tersebut. Jadi dapat diambil kesimpulan bahwa sistem adalah sekelompok komponen yang saling berhubungan dan bekerja sama untuk mencapai suatu tujuan bersama. (Indrajani, 2015)

\section{b. Miktokontroler}

Mikrokontroler merupakan sebuah sistem komputer yang seluruh atau sebagian besar elemennya dikemas dalam satu chip IC, sehingga sering disebut single chip microcomputer. Lebih lanjut, mikrokontroler merupakan sistem komputer yang mempunyai satu atau beberapa tugas yang sangat spesifik, berbeda dengan PC yang memiliki beragam fungsi.Perbedaan lainnya adalah perbandingan RAM dan ROM yang sangat berbeda antara komputer dengan mikrokontroler. Dalam mikrokontroler, ROM jauh lebih besar disbanding RAM, sedangkan dalam komputer atau PC RAM jauh lebih besar disbanding ROM.(Wahyudin, 2007)

\section{c. Arduino Uno}

Arduino dikatakan sebagai sebuah platform dari physicalcomputing yang bersifat open source.Pertama-tama perlu dipahami bahwa "platform" di sini adalah sebuah pilihan kata yang tepat.Arduino tidak hanya sekedar sebuah alat pengembangan, tetapi ia adalah kombinasi dari hardware, bahasa pemograman dan Integarted Development Environment (IDE) yang canggih. Ada banyak modul pendukung (sensor, tampilan, penggerak, dan sebagainya) yang dibuat oleh pihak lain untuk bisa disambungkan dengan Arduino. Arduino berevolusi menjadi sebuah platform karena ia menjadi pilihan dan acuan bagi banyak praktisi. Salah satu yang membuat Arduino memikat hati banyak orang adalah karena sifatnya yang open source, baik untuk hardware maupun software-nya. Diagram rangkain elektronik Arduino digratiskan untuk semua orang. Anda bisa bebas men-download gambarnya, membeli komponen-komponennya, membuat PCB-nya dan merangkainya sendiri tanpa harus membayar kepada para pembuat Arduino.Sama halnya dengan IDE Arduino yang bisa di-download dan diinstal pada computer secara gratis.(Sanjaya, 2016)

Menurut (Afrie Setiawan, 2010) Arduino Uno adalah salah satu produk nerlabel Arduino yang sebenarnya adalah suatu papan elektronik yang mengandung mikrokontroler ATmega328 (Sebuah keeping yang secara fungsional bertindak seperti sebuah komputer).Peranti ini dapat dimanfaatkan untuk mewujudkan rangkaian elektronik dari yang sederhana hingga yang kompleks.Arduino Uno mengandung mikroprosesor (berupa Armel AVR) dan dilengkapi dengan oscillator $16 \mathrm{MHz}$ (yang memungkinkan operasi berbasis waktu dilaksanakan dengan tepat), dan regulator (pembangkit tegangan) 5 volt.(Ridarmin \& Pertiwi, 2018)

\section{d. IDE Arduino}

IDE (Integrated Development

Environtment) adalah sebuah program aplikasi yang digunakan untuk menuliskan program beserta pengujiannya.(Setiawan, 2006) 
IN F ORM A IK A

Jurnal Informatika, Manajemen dan Komputer, Vol.11 No.2, Desember 2019

eISSN :2580-3042

pISSN : 1979-0694

\section{e. Flowchart}

Bagan alir (flowchart) adalah bagan (chart) yang menunjukan alir (flow) di dalam program atau prosedur sistem secara logika. Bagan alir digunakan terutama untuk alat bantu desain proses. Pada waktu akan menggambarkan suatu bagan alir, analis sistem atau pemograman dapat mengikuti pedoman berikut:

a. Bagan alir sebaiknya digambar dari atas ke bawah dan mulai dari bagian kiri dari suatu halaman.

b. Kegiatan di dalam bagan alir harus ditunjukan dengan jelas.

c. Harus ditunjukan dari mana kegiatan akan dimulai dan dimana akan berakhirnya.

d. Masing-masing kegiatan di dalam bagan alir sebaiknya digunakan suatu kata yang mewakili suatu pekerjaan.

e. Masing-masing kegiatan di dalam bagan alir harus di dalam urutan yang semestinya.

f. Kegiatan yang terpotong dan akan disambung di tempat lain harus ditunjukan dengan jelas menggunakan simbol penghubung.

Gunakanlah simbol-simbol bagan alir yang standar..(HM, 2005)

Tabel 1. Simbol-Simbol Flowchart

\begin{tabular}{|c|c|c|}
\hline No & Simbol & Keterangan \\
\hline 1 & & \begin{tabular}{lr}
\multicolumn{2}{l}{ Simbol input/output. } \\
Digunakan \\
mewakili \\
input/output.
\end{tabular} \\
\hline 2 & & $\begin{array}{lr}\text { Simbol } & \text { Proses. } \\
\text { Digunakan } & \text { untuk } \\
\text { mewakili suatu proses. }\end{array}$ \\
\hline 3 & & $\begin{array}{l}\text { Simbol Garis Alir. } \\
\text { Digunakan untuk } \\
\text { menunjukkan arus dari } \\
\text { proses. }\end{array}$ \\
\hline 4 & & $\begin{array}{l}\text { Simbol Penghubung. } \\
\text { Digunakan untuk } \\
\text { menunjukkan } \\
\text { sambungan dari bagan } \\
\text { alir yang terputus. Baik } \\
\text { pada halaman yang } \\
\text { sama maupun di } \\
\text { halaman berikutnya. }\end{array}$ \\
\hline 5 & & $\begin{array}{l}\text { Simbol Keputusan. } \\
\text { Digunakan untuk suatu } \\
\text { penyelesaian kondisi di } \\
\text { dalam program. }\end{array}$ \\
\hline
\end{tabular}

\begin{tabular}{|l|l|l|}
\hline \multicolumn{1}{|c|}{} & \multicolumn{2}{|l|}{$\begin{array}{l}\text { Simbol Proses } \\
\text { Terdefinisi. Digunakan } \\
\text { untuk menunjukkan } \\
\text { suatu operasi yang } \\
\text { rinciannya ditunjukkan } \\
\text { di tempat lain. }\end{array}$} \\
\hline 7 & $\square$ & $\begin{array}{l}\text { Simbol Persiapan. } \\
\text { Digunakan untuk } \\
\text { memberi/menset nilai } \\
\text { awal suatu besaran. }\end{array}$ \\
\hline 8 & $\square$ & $\begin{array}{l}\text { Simbol Titik Terminal. } \\
\text { Digunakan untuk } \\
\text { menunjukkan awal dan } \\
\text { akhir dari suatu proses }\end{array}$ \\
\hline
\end{tabular}

Sumber : (HM, 2005)

\section{f. Motor DC}

Motor bekerja bedasarkan prinsip induksi magnetic. Sirkuit internal motor DC terdiri dari kumparan/lilitan konduktor. Setiap arus yang mengalir melalui sebuah konduktor akan menilmbulkan medan magnet. Konduktor dibentuk menjadi sebuah loop sehingga ada dua bagian konduktor yang berada di dalam medan magnet pada saat yang sama.(Wicaksono \& Hidayat, 2017)

\section{g. Modul Driver L298N}

Menurut Krause (2002), Driver motor L298N merupakan driver motor yang paling populer digunakan untuk mengontrol kecepatan dan arah pergerakan motor terutama pada robot line foller / line tracer. Kelebihan dari driver motor L298N ini adalah cukup presisi dalam mengontrol motor.Selain itu, kelebihan driver motor L298N adalah mudah untuk dikontrol. Pada prinsipnya rangkaian driver motor L298N ini dapat mengatur tegangan dan arus sehingga kecepatan dan arah motor dapat diatur. Kelebihan akan modul driver motor L298N ini yaitu dalam hal kepresisian dalam mengontrol motor sehingga motor lebih mudah untuk dikontrol. (Sudaryoto \& Zuhrie, 2019)

h. LCD

LCD yang digunakan adalah LCD 16x2 yang berarti 16 kolom (untuk 16 karaker) dan 2 baris. Tabel 2.menunjukan fungsi dari setiap pin LCD 16x2.(Wicaksono \& Hidayat, 2017)

Menurut (Dinata \& Sunanda, 2015), kegunaan Liquid Crystal Display (LCD) banyak sekali dalam perancangan suatu sistem dengan menggunakan mikrokontroler, Liquid Crystal Display (LCD) dapat berfungsi untuk 
INFORM T IKA

Jurnal Informatika, Manajemen dan Komputer, Vol.11 No.2, Desember 2019

eISSN :2580-3042

pISSN : 1979-0694

menampilkan suatu nilai hasil sensor, menampilkan teks, atau menampilkan menu pada aplikasi mikrokontroler. Modul Liquid Crystal Display (LCD) matrix tersedia dengan konfigurasi 16 karakter dan 2 baris dengan setiap karakternya dibentuk oleh baris pixel.Adapun fitur yang disajikan.(Rosmaniila, Radillah, \& Sofiyan, 2018)

Tabel 2. Fungsi Pin LCD 16x2

\begin{tabular}{|c|c|c|}
\hline No & Nama Pin & Fungsi \\
\hline 1 & VSS & Ground \\
\hline 2 & VCC & $+5 \mathrm{~V}$ \\
\hline 3 & VEE & Tegangan Kontras \\
\hline 4 & $\mathrm{RS}$ & $\begin{array}{l}\text { Register Select } \\
0=\text { Register Instruksi } \\
1=\text { Register Data }\end{array}$ \\
\hline 5 & $\mathrm{R} / \mathrm{W}$ & $\begin{array}{l}\text { Read/Write } \\
0=\text { Mode Tulisa } \\
1=\text { Mode Baca }\end{array}$ \\
\hline 6 & $\mathrm{E}$ & $\begin{array}{l}\text { Enable } \\
0=\text { Enable } \\
1=\text { Disable }\end{array}$ \\
\hline 7 & $\mathrm{DB}_{0}$ & Data bit 0 (LSB) \\
\hline 8 & $\mathrm{DB}_{1}$ & Data bit 1 \\
\hline 9 & $\mathrm{DB}_{2}$ & Data bit 2 \\
\hline 10 & $\mathrm{DB}_{3}$ & Data bit 3 \\
\hline 11 & $\mathrm{DB}_{4}$ & Data bit 4 \\
\hline 12 & $\mathrm{DB}_{5}$ & Data bit 5 \\
\hline 13 & $\mathrm{DB}_{6}$ & Data bit 6 \\
\hline 14 & $\mathrm{DB}_{7}$ & Data bit 7 \\
\hline 15 & BPL & Back Panel Lig \\
\hline 16 & GND & Ground \\
\hline
\end{tabular}

Sumber : (Wicaksono \& Hidayat, 2017)

\section{i. Keypad}

Salah satu jenis perangkat antar muka yang umum dijumpai pada sistem embedded adalah keypad membrane 3x4 atau 4x4. Keypad

biasanya digunakan pada beberapa peralatan yang berbasis mikrokontroller.Keypad berfungsi sebagai interface antara perangkat (mesin) elektronik dengan manusia atau dikenal dengan istilah HMI (Human Machine Interface). Keypad membrane 4x3 adalah keypad dengan jumlah kolom 3 dan jumlah baris 4 yang dapat digunakan, sedangkan keypad membrane 4x4 adalah keypad dengan jumlah kolom 4 dan jumlah baris 4 yang dapat digunakan. (Syabibi \& Subari, 2016)

\section{METODOLOGI PENELITIAN}

Kerangka Penelitian yang digunakan digunakan dalam penelitian ini adalah sebagai berikut :

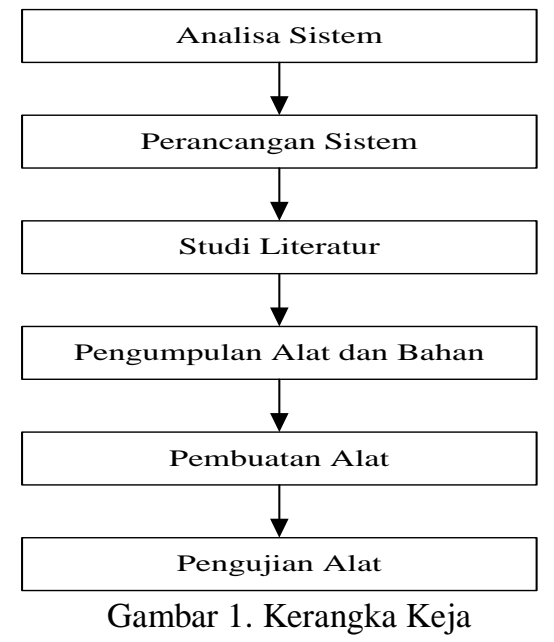

Berdasarkan gambar 1 diatas, dapat dijabarkan urutan-urutan langkah kerja sebagai berikut:

1. Analisa Sistem

Tahapan ini merupakan kegiatan menemukan atau mengidentifikasikan masalah, mengevaluasi, membuat model serta membuat spesifikasi, seperti menganalisa dan merancang alat yang akan dibuat.

2. Perancangan sistem

Tahapan ini merupakan perancangan sistem alat dimulai dengan memodelkan sistem yang akan dibangun dan menentukan aplikasi yang digunakan untuk membangun perancangan sistem alat peniris minyak otomatis, seperti mendesain rangkaian alat dan menggunakan software yang dapat menyambungkan dari komponen satu ke komponen lain. Software yang akan digunakan adalah Arduino IDE 1.8.9.

3. Studi Literatur

Dalam penelitian ini dibutuhkan literatur maupun referensi untuk mengetahui solusi, cara atau metode yang akan digunakan dalam 


\section{INFORM TIK}

Jurnal Informatika, Manajemen dan Komputer, Vol.11 No.2, Desember 2019

eISSN :2580-3042

pISSN : 1979-0694

pemecahan masalah yang ada. Studi pustaka meliputi pemahaman tentang pengetahuan tentang bagaimana cara membangun sebuah alat peniris minyak otomatis, sumber didapat dari buku, jurnal dan internet. Seperti mencari buku dan jurnal yang sesusai dengan teori yang kita gunakan, seperti kita menggunakan Arduino, buku dan jurnal yang kita cari judulnya adalah tentang Arduino.

4. Pengumpulan Alat dan Bahan

Tahapan ini merupakan pengumpulan alat dan bahan yang digunakan untuk pembuatan alat peniris minyak otomatis. Seperti kit Arduino Uno, motor DC, modul driver L298N, modul driver $12 \mathrm{C}$, adaptor $\mathrm{AC}$ to $\mathrm{DC} 12 \mathrm{~V} 1 \mathrm{~A}, \mathrm{LCD}$ 16x2, keypad, buzzer.

5. Pembuatan Alat

Tahapa ini merupakan memulai merangkai atau merancang alat dengan bahan-bahan yang sudah disiapkan.Sesuai dengan logika yang udah di pikirkan untuk membuat peniris minyak otomatis.Seperti merangkai satu demi satu alat atau bahan yang sudah kita sediakan kemudian setelah di rangkai masukan logika kedalam Arduino menggunakan software yang mendukung sehingga alat bisa bekerja.

6. Pengujian Alat

Setelah alat yang selesai dirancang dan dibuat maka perlu dilakukan pengujian apakah alat ini bisa berjalan sesuai dengan yang telah direncanakan dan sesuai dengan tujuan penelitian.Seperti pengujian terhadap alat dimana Arduino telah menerima logika untuk bisa menggerakan alat tersebut.

3. HASIL DAN PEMBAHASAN

\section{a. Perancangan Rangkaian Keseluruhan}

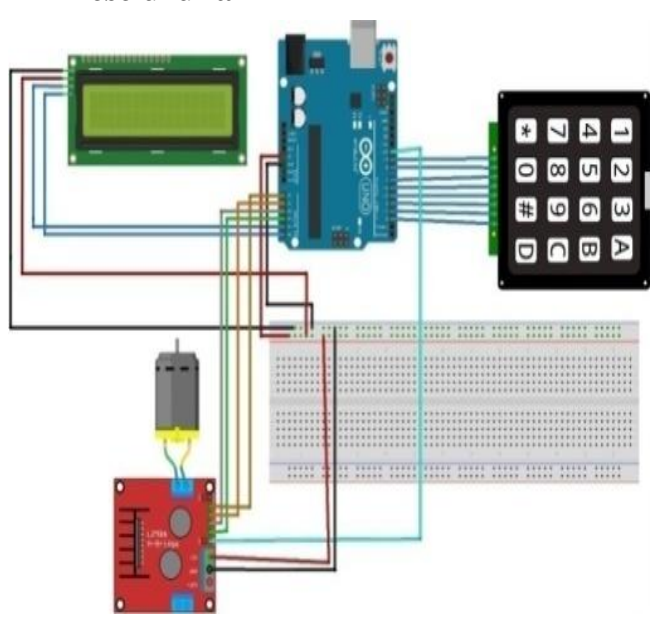

Gambar 2. Perancangan Rangkaian Alat Secara Keseluruhan

Alat

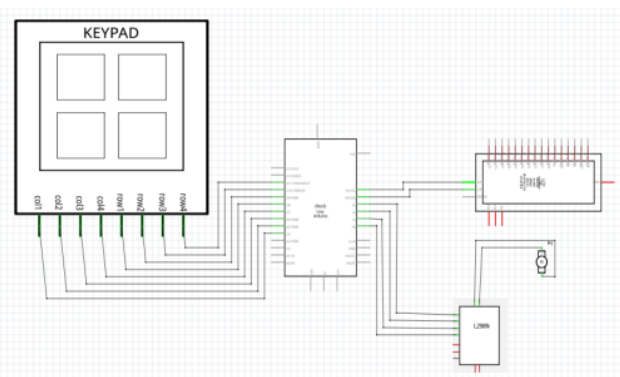

Gambar 3. Rangkain Skematika Alat Secara Keseluruhan

Gambar diatas merupakan perancangan rangkaian alat peniris minyak secara keseluruhan dengan Motor DC. Pada gambar, tampak sambungan antara komponen perangkat keras, yaitu Arduino Uno ke keyped, Arduino Uno ke LCD, Arduino Uno ke Modul Driver L298N dan Modul Driver L298N ke Motor DC.

\section{b. Desain Rancangan Alat}

Desain perancangan alat menggambarkan rancangan alat yang sudah dibuat, adapun desain rancangan alat sebagai berikut :

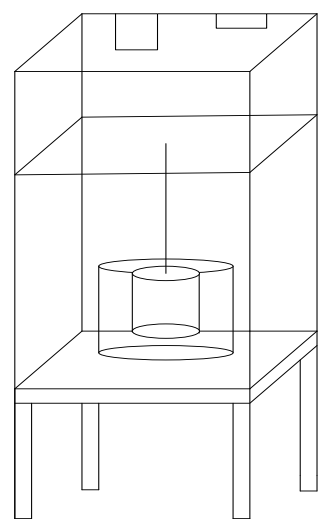

Gambar 4. Desain Rancangan Alat

\section{c. Flowchart Alat}

Agar cara kerja yang dirancang dapat dipahami, maka perlu dibuat pemodelan logika dan algoritma berupa gambar flowchart yang terkandung pada alat peniris minyak otomatis ini. Gambaran secara singkat proses kerja atau alur kerja dimulai dari proses start kemudian komponen alat dalam keadaan standby. Alat dan komponen-komponen yang digunakan diset secara keseluruhan, selanjutnya proses pengiputan kecepatan dan waktu pada keypad dan arduino memberikan perintah sehingga LCD dapat menampilkan nilai dari kecepatan dan waktu yang telah di input sebelumnya. 
IN F ORMA T I K A

Jurnal Informatika, Manajemen dan Komputer, Vol.11 No.2, Desember 2019

eISSN :2580-3042

pISSN : 1979-0694
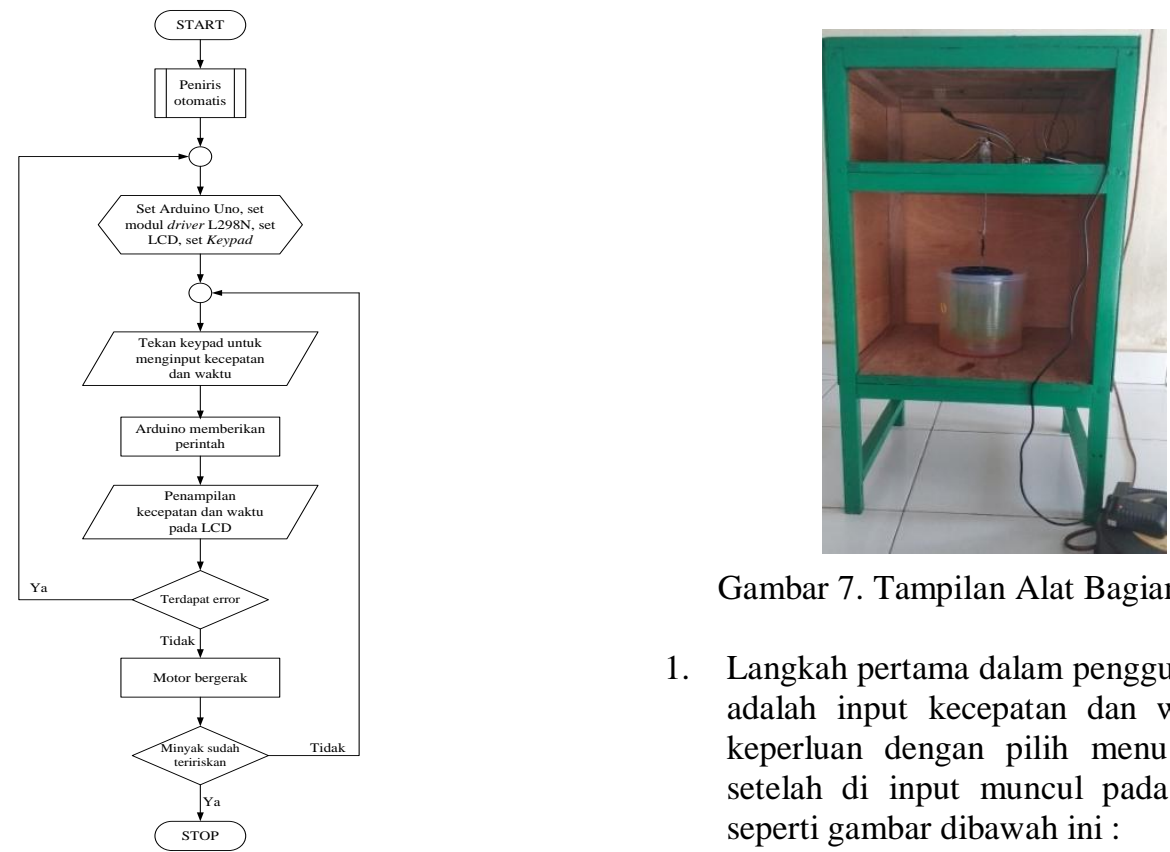

Gambar 7. Tampilan Alat Bagian Depan

1. Langkah pertama dalam penggunaan alat ini adalah input kecepatan dan waktu sesuai keperluan dengan pilih menu set config, setelah di input muncul pada layar LCD seperti gambar dibawah ini :

Gambar 5.Flowchart Cara Kerja Alat

Tabel 3 Rincian Perbandingan

\begin{tabular}{|c|c|c|c|}
\hline No & Kecepatan & Waktu & $\begin{array}{c}\text { Hasil } \\
\text { Tirisan }\end{array}$ \\
\hline 1 & $\begin{array}{c}\text { Level 1: } \\
150 \mathrm{rpm}\end{array}$ & $\begin{array}{c}\text { Timer } 1: \\
15 \\
\text { second }\end{array}$ & $\begin{array}{l}\text { Cukup } \\
\text { Bagus }\end{array}$ \\
\hline 2 & $\begin{array}{c}\text { Level 2: } \\
200 \mathrm{rpm}\end{array}$ & $\begin{array}{c}\text { Timer } 2: \\
30 \\
\text { second }\end{array}$ & Bagus \\
\hline 3 & $\begin{array}{c}\text { Level 3: } \\
255 \mathrm{rpm}\end{array}$ & $\begin{array}{c}\text { Timer } 3: \\
60 \\
\text { second }\end{array}$ & $\begin{array}{c}\text { Sangat } \\
\text { Bagus }\end{array}$ \\
\hline
\end{tabular}

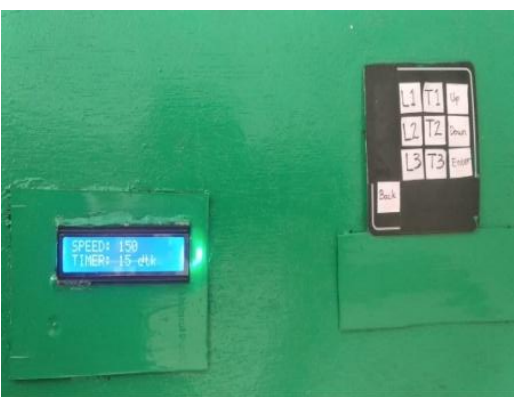

Gambar 8. Hasil Input Dari Kecpatan dan Waktu

2. Setelah kecepatan dan waktu sudah di input selanjutnya kembali ke menu dan pilih menu mulai untuk memulai penirisan, seperti pada tampilan layar LCD dibawah ini :

diatas, dapat disimpulkan bahwa semakin laju kecepatan dan semakin lama waktu yang di gunakan maka hasil dari tirisan akan semakin bagus.

\section{d. Cara Menggunakan Alat dan Program}

Pada bagian ini akan dijelaskan petunjuk cara pengoperasian pada alat yang telah dirancang dengan benar dan juga menampilkan serta menginput koding ke Arduino.

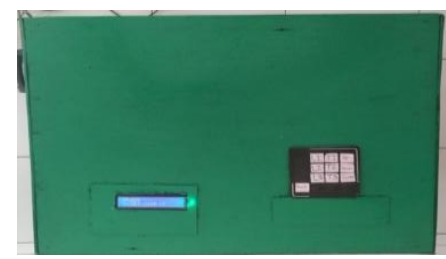

Gambar 6. Tampilan Alat Bagian Atas

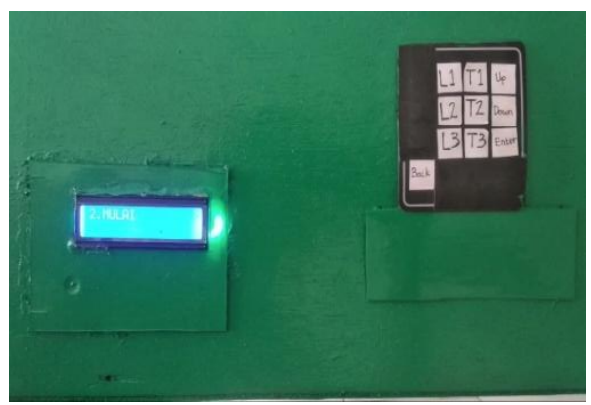

Gambar 9. Tampilan Dari Menu Mulai

3. Langkah kedua adalah cara menginput koding ke Arduino, hubungkan kabel USB ke portArduino, seperti pada gambar dibawah ini : 
IN F ORM A IK A

Jurnal Informatika, Manajemen dan Komputer, Vol.11 No.2, Desember 2019

eISSN :2580-3042

pISSN : 1979-0694

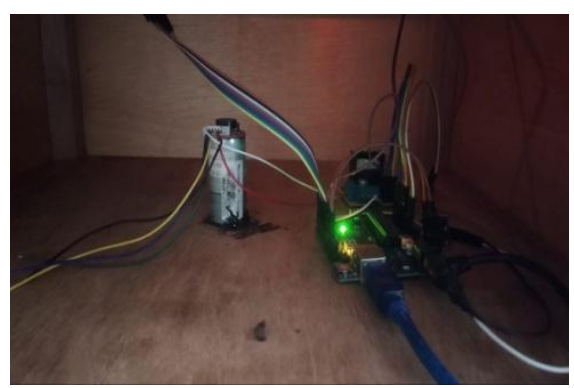

Gambar 10. Kabel USB Terhubung dengan port Arduino

4. Setelah itu hubungkan ujung kabel USB Arduino ke leptop, seperti pada gambar dibawah ini :

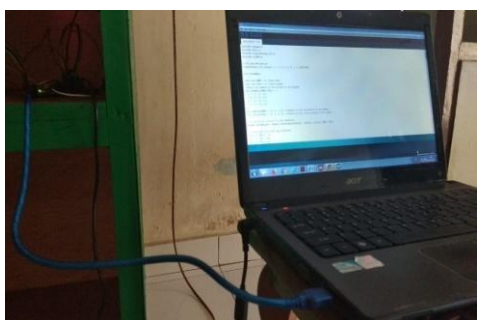

Gambar 11. Laptop Terhubung dengan Arduino

5. Selanjutnya input koding ke Arduino yang telah di ketik, seperti pada gambar dibawah ini :

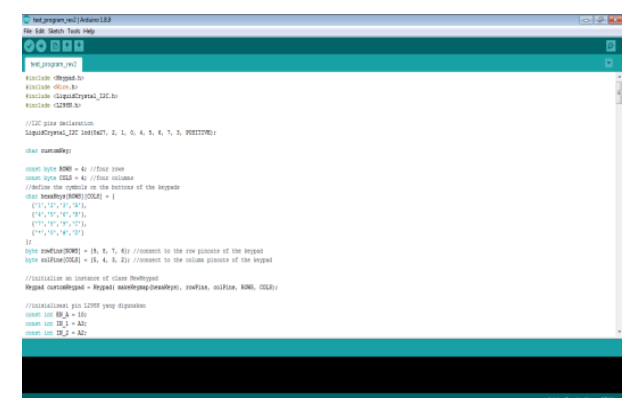

Gambar 12. Tampilan Listing Program

\section{KESIMPULAN}

Dengan hasil penelitian tersebut di atas dapat diambil kesimpulan yaitu:

1. Alat mampu meniriskan minyak pada keripik sehingga alat peniris akan berhenti sesuai dengan waktu yang diperlukan.

2. Membantu dan mempercepat para pekerja dalam melakukan penirisan.

3. Semua keripik dapat dikemas tanpa harus mengkhawatirkan banyaknya minyak pada keripik.

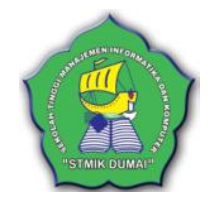

\section{REFERENSI}

HM, J. (2005). Analisa dan Desaign. Yogyakarta: Penerbit Andi.

Indrajani. (2015). Database Desaign. Jakarta: PT. Elex Media Komputindo.

Ridarmin, \& Pertiwi, Z. P. (2018). Prototype Penyiram Tanaman Hias Dengan Soil Moisture Sensor Berbasis Arduino. Jurnal Informatika, Manajemen Dan Komputer, 10(1), 7-11. Retrieved from http://www.ejournal.stmikdumai.ac.id/inde x.php/path/article/view/54

Rosmaniila, Radillah, T., \& Sofiyan, A. (2018). I $\mathrm{n} \mathrm{f}$ o $\mathrm{r} \mathrm{m}$ a t i k a. Jurnal Informatika, Manajemen Dan Komputer, 10(1), 32-38.

Sanjaya, M. (2016). Panduan Praktis Pemograman Robot Vision Menggunakan Matlab dan IDE Arduino. Yogyakarta: Penerbit Andi.

Setiawan, S. (2006). Mudah dan Menyenangkan Belajar Mikrokontroler. Yogyakarta: Penerbit Andi.

Sudaryoto, S. B., \& Zuhrie, M. S. (2019). Rancang Bangun Sistem Kontrol Ketinggian Air Bendungan Berbasis Fuzzy Logic Controller. Jurnal Teknik Elektro, 8(2), 401-109. Retrieved from https://jurnalmahasiswa.unesa.ac.id/index.p hp/JTE/article/view/27250

Syabibi, M. K., \& Subari, A. (2016). Rancang Bangun Sistem Monitoring Keamanan Rumah Berbasis WEB Menggunakan Raspberry PI B+ Sebagai Server dan Media Kontrol. Jurnal Gema Teknologi, 19(1), 22-29. Retrieved from https://ejournal.undip.ac.id/index.php/gema _teknologi/article/view/21959

Wahyudin, D. (2007). Belajar Mudah Mikrokontroler AT89s52 dengan Bahasa BASIC Menggunakan BASKOM-8051. Yogyakarta: Penerbit Andi.

Wicaksono, M. F., \& Hidayat. (2017). Mudah Belajar Mikrokontroler Arduino. Yogyakarta: Penerbit Andi. 